\title{
Ethos discursivo e o comportamento enunciativo: a construção de si de comentaristas de notícias de divulgação científica da revista Superinteressante online
}

\author{
Discursive Ethos and Enunciative Performance: self-construction of commentators \\ in scientific popularization texts from the magazine Superinteressante online
}

\author{
Ethos discursivo y comportamiento enunciativo: la autoconstrucción de los periodistas \\ de noticias de la divulgación científica de la revista Superinteressante en línea \\ Maria Eduarda Giering ${ }^{1} 1$ \\ Eduardo Paré Glück ${ }^{1} 1$ \\ ${ }^{1}$ Universidade do Vale do Rio dos Sinos, São Leopoldo, RS, Brasil.
}

$\diamond$

\begin{abstract}
RESUMO
Este artigo dedica-se ao estudo de textos do gênero comentário online, escritos por leitores de notícias de divulgação da ciência do site da revista Superinteressante online. O objetivo é conhecer, no âmbito desse gênero próprio do webjornalismo, como os leitores-comentaristas constroem seu ethos discursivo na interação com o interlocutor. Para a análise, investigamos, a partir de marcas do comportamento enunciativo do comentarista, a imagem que ele dá de si para legitimar a sua fala. Valemo-nos, do ponto de vista teórico, de categorias do Modo de Organização Enunciativo, postuladas por Charaudeau (2008) e de conceitos de ethos discursivo de Maingueneau (2010) e de Amossy (2005). Os resultados mostram que a atenção ao comportamento enunciativo dos leitores-comentaristas nos leva à construção do ethos discursivo projetado. Eles atribuem-se a papéis que os autorizam a julgar, a opinar, a interpelar, tudo isso respaldado por um fiador, construído na cenografia, que concede legitimidade para as suas críticas.
\end{abstract}

Palavras-chave: Ethos discursivo. Comportamentos enunciativos. Cenografia. Comentário online. Divulgação da ciência.

\begin{abstract}
This paper studies texts from the genre online comment, produced by readers of scientific popularization texts from the magazine Superinteressante website. The aim is to verify, in this webjournalism genre, how the commentator-readers build their discursive ethos in the interaction with their interlocutors. In the analysis, we investigate, by means of marks of the commentators' enunciative performances, the image of themselves they provide in order to validate their speech. The theoretical basis of this study is composed of the categories of Enunciative Organization Modes, proposed by Charaudeau (2008), and Mainguenau's (2010) and Amossy's (2005) concepts of discursive ethos. The results show that the attention to the enunciative behavior of the reader-commentators leads us to the construction of the projected discursive ethos. They are given roles that authorize them to judge, to opine, to question, all backed by a guarantor, built in the scenography, who gives legitimacy to their criticism.
\end{abstract}

Keywords: Discursive ethos. Enunciative performances. Scenography. Online comment. Science popularization.

\section{RESUMEN}

Este artículo está dedicado al estudio de géneros de comentarios en línea, escrito por lectores de noticias de divulgación científica del sitio web Superinteressante en línea. El objetivo es saber, dentro de este género de periodismo web, cómo los lectores-comentaristas construyen su espíritu discursivo en interacción con el interlocutor. Para el análisis, investigamos, a partir de las marcas del comportamiento enunciativo del comentarista, la imagen que él da de sí mismo para legitimar su discurso. Utilizamos, desde el punto de vista teórico, las categorías 
del Modo de Organización Enunciativo, postuladas por Charaudeau (2008) y los conceptos de ethos discursivo por Maingueneau (2010) y Amossy (2005). Los resultados muestran que la atención al comportamiento enunciativo de los lectores-comentaristas nos lleva a la construcción del ethos discursivo proyectado. Se les asignan roles que los autorizan a juzgar, a opinar, a cuestionar, todo respaldado por un garante, construido en la escenografía, que da legitimidad a sus críticas.

Palabras clave: Ethos discursivo. Comportamientos enunciativos. Escenografía. Comentario en línea. Difusión de la ciencia.

\section{Introdução}

Qual a imagem que os comentaristas fazem de si quando tomam a palavra para interagir com as notícias de divulgação científica publicadas na revista Superinteressante online? Essa pergunta norteou a pesquisa que realizamos em um corpus composto de 40 notícias (e seus comentários) publicadas na aba de Ciência do site ${ }^{1}$ da revista. O objetivo foi conhecer como se constrói a interação do leitor desse tipo de notícia, considerando o Modo de Organização Enunciativo que se evidencia nos comentários. Realizamos pesquisas relativas à divulgação científica midiática desde 2007 e chamounos atenção o papel discursivo do leitor-comentarista nas notícias divulgadas em revistas de popularização.

Ao nos voltarmos para os gêneros midiáticos que circulam na web, estamos no âmbito do webjornalismo, conforme denominação de Canavilhas (2014). O autor, baseado na premissa de que o conceito de jornalismo se encontra sempre relacionado com o suporte técnico e com o meio que permite a difusão das notícias (jornalismo impresso, radiojornalismo, telejornalismo), introduz o conceito de webjornalismo, ou seja, o jornalismo que se realiza na web.

A evolução das várias gerações de internet permite que o jornalismo na web ganhe uma nova dimensão e apresente características próprias, dentre elas se destaca a Interatividade, ou seja, a possibilidade de interação direta com o produtor de notícias ou de opiniões. Para Canavilhas (2001, p. 2), “a máxima 'nós escrevemos, vocês leem' pertence ao passado". Diferentemente do jornalismo tradicional, o leitor na web tem a oportunidade de interagir de imediato sobre o conteúdo que lê, especialmente quando, após a publicação da notícia, há espaço para comentários.

Voltando-nos para a divulgação científica na mídia, interessa-nos conhecer o ethos discursivo dos comentaristas de notícias na web, nesse caso, das notícias sobre ciência publicadas na Superinteressante online, veículo que atinge um público predominantemente jovem.

\footnotetext{
1 Disponível em: https://super.abril.com.br/. Acesso em: 30 mar. 2017.
}

Gostaríamos de saber como esse público interage com as notícias de divulgação científica (DC) publicadas no site da revista e, para isso, observamos o comportamento enunciativo manifestado nos textos.

A realização dessa investigação se sustenta em conceitos advindos da área da Comunicação - Rost (2006; 2014); Canavilhas (2001; 2014); Palacios (2002); de postulados de Charaudeau $(2008 ; 2016)$ sobre o discurso de midiatização da ciência e acerca do Modo de Organização Enunciativo, e, ainda, de considerações de Maingueneau (2010) e Amossy (2005) quanto ao conceito de ethos discursivo.

\section{Fundamentação teórica: da divulgação da ciência na mídia ao ethos}

Esta pesquisa se insere no conjunto de investigações realizadas pelo Grupo de Pesquisa do CNPq intitulado Comunicação da Ciência: Estudos Linguístico-Discursivos (CCELD). Um dos focos do grupo é estudar a divulgação científica midiática (DCM) que tem lugar no meio digital e que é dirigida a um público não especializado, sejam publicações em revistas DC de grande circulação, em sua versão digitalizada, ou postagens sobre ciência que circulam nas diferentes redes sociais no Brasil.

Ao nos voltarmos para a mídia de divulgação científica, situamo-nos no domínio midiático, que, conforme Charaudeau (2016), caracteriza-se por uma dupla finalidade: informar e captar o público leitor para os temas da ciência. As notícias que são divulgadas na Superinteressante online obedecem a essas visadas, pois, ao mesmo tempo em que divulgam resultados de pesquisas ou descobertas científicas, buscam sensibilizar o leitor para a leitura dos textos, além de captar a sua atenção com objetivos mercadológicos, ou seja, com o intuito de fidelizar o leitor na busca da revista e de seu conteúdo na web. Dessa forma, estabelece-se um contrato de comunicação ${ }^{2}$ (CHARAUDEAU, 2008)

\footnotetext{
Para Charaudeau (2006), o Contrato de Comunicação se estabelece quando os interlocutores reconhecem as condições de realização da troca linguageira em que estão envolvidos.
} 
entre a revista e seus leitores. No caso do webjornalismo praticado pela Superinteressante online, esse contrato vem acrescido de características da prática jornalística no meio digital: hipertextualidade, multimedialidade, interatividade, memória, instantaneidade e ubiquidade (PALACIOS, 2002). Nesta pesquisa, estamos no âmbito da interatividade.

A interatividade, segundo Rost (2014), é um dos pilares do webjornalismo, porque permite abordar o espaço de relação entre jornalista e leitor e analisar as diferentes instâncias de seleção, intervenção e participação nos conteúdos do meio. Para Primo e Träsel (2006), essa participação já ocorria no jornalismo tradicional através de cartas e ligações, por exemplo, na forma de sugestões de pauta ou mesmo para alguma seção do tipo "cartas do leitor". Porém, conforme os autores, "a filtragem daquelas cartas, o pequeno espaço disponível para sua publicação e a necessidade de utilização de outro meio para envio (não se pode responder através da televisão) acabavam por desestimular uma maior participação" (PRIMO; TRÄSEL, 2006, p. 3).

Os comentários dos leitores após as notícias caracterizam uma interatividade comunicativa (ROST, 2006), uma vez que há interação entre pessoas (jornalista e leitor) e não apenas com a máquina ou o sistema; além disso, o usuário é também produtor de conteúdo e o resultado de sua participação é pública. Por meio das opções interativas, o leitor procura dialogar, discutir, confrontar, apoiar e, de uma forma ou de outra, entabular uma relação com outros. Essas características apontam para o fato de que os comentários dos leitores-usuários oferecem um material significativo para análise textualdiscursiva, pois o leitor, ao tomar a palavra para interagir com seu interlocutor, torna-se protagonista da interação.

O estudo que realizamos dos comentários das notícias de DC publicadas na Superinteressante online busca evidenciar, por meio do comportamento enunciativo dos leitores-comentaristas, como se constrói a interação do leitor desse tipo de notícias, considerando o Modo de Organização Enunciativo que se evidencia nos comentários.

\subsection{Ethos discursivo e Modo de Organização Enunciativo}

Para esta investigação, valemo-nos da noção de ethos discursivo a partir dos postulados de Maingueneau (2001; 2005; 2010) e de Amossy (2005). Maingueneau (2001), ao tratar do tema, afirma que, por meio da enunciação, revela-se a personalidade do enunciador. Segundo o linguista, todos os discursos, sejam orais ou escritos, possuem um tom que dá autoridade ao que é dito. "Esse tom permite ao leitor construir uma representação do corpo do enunciador (e não, evidentemente, do corpo do autor efetivo). A leitura faz, então, emergir uma instância subjetiva que desempenha o papel de fiador do que é dito" (MAINGUENEAU, 2001, p.98). A qualidade do ethos remete, segundo Maingueneau (2001, p. 99), “à imagem desse "fiador", que, por meio de sua fala, confere a si próprio uma identidade compatível com o mundo que ele deverá construir em seu enunciado". O linguista postula que é por meio de seu próprio enunciado que o fiador deve legitimar sua maneira de dizer.

O ethos, dessa forma, depende da cena genérica que o sustenta. Maingueneau postula que o discurso pressupõe uma cena de enunciação para poder ser enunciado; ao mesmo tempo, o discurso deve validar a sua própria enunciação: "qualquer discurso, por seu próprio desdobramento, pretende instituir a situação de enunciação que o torna pertinente" (MAINGUENEAU, 2005, p. 75).

A cena de enunciação que pleiteia Maingueneau (2010; 2015) é composta de três cenas: cena englobante, cena genérica e cenografia. A englobante corresponde ao que o linguista chama de tipo de discurso (literário, midiático, jurídico), que confere ao discurso seu estatuto pragmático. Trata-se de proceder a um recorte de um setor da atividade social caracterizável por uma rede de gêneros de discurso. No nosso caso, trata-se do discurso midiático, ou, mais precisamente, do webjornalismo. A cena genérica relaciona-se ao gênero discursivo, ou seja, conforme o autor, a uma "instituição discursiva" (MAINGUENEAU, 2005, p. 75). Comenta Amossy (2005, p. 137) sobre a cena genérica: "no interior de uma dada cena genérica, o locutor procede à instalação de uma imagem de si que corresponde a uma distribuição de papéis preexistentes e se funda nos lugares comuns do auditório ou, ao menos, nos que o locutor the atribui”. Em nossa pesquisa, trata-se do gênero comentário online.

A cenografia, a terceira cena postulada por Maingueneau, constrói-se, segundo o autor, pelo próprio texto, constituindo-se em uma enunciação singular, já que as normas constitutivas da cena genérica não bastam para dar conta da singularidade de um texto. Maingueneau (2006, p. 113) esclarece: "a escolha da cenografia não é indiferente: o discurso, desenvolvendo-se a partir de sua cenografia, pretende convencer instituindo a cena de enunciação que o legitima".

Para Amossy (2005, p. 142), a cena de enunciação construída pelo discurso tem uma dimensão discursiva e institucional, pois não é puramente imaginária. De acordo com a linguista, "a construção discursiva de uma imagem de si é suscetível de conferir ao orador sua autoridade, isto é, o poder de influir nas opiniões e de modelar atitudes", o que configura uma posição pragmática. "O proferimento do discurso ou a colocação de um texto em circulação 
conferem certa realidade à distribuição de papéis e às imagens do orador que eles autorizam" (AMOSSY, 2005, p. 138).

Ao estudarmos os comentários dos leitores de notícias sobre ciências do site da Superinteressante online, adotamos a posição dos dois autores, que se complementam, considerando a cena da enunciação que compõe os comentários. Esses constituem, aliás, um corpus privilegiado, pois os leitores-comentaristas, embora ocupem lugares dados constitucionalmente pelas cenas englobante e genérica em questão, precisam construir uma encenação na qual erigem sua legitimidade para falar.

Com o objetivo de conhecer como os leitorescomentaristas constroem seu ethos discursivo na interação com o interlocutor, voltamo-nos para as marcas linguísticas do Modo de Organização Enunciativo, de acordo com Charaudeau (2008), presentes nos comentários. Assim o define o linguista:

O modo de organização enunciativo permite organizar a colocação em cena dos protagonistas da enunciação (eu, tu, ele), sua identidade e suas relações, com o auxílio da modalização, igualmente denominados 'papéis enunciativos' (alocutivo, elocutivo e delocutivo) (CHARAUDEAU, 2004, p. 338, grifo nosso).

O Modo Enunciativo, categoria de discurso que aponta para a maneira como o sujeito falante age na encenação do ato de comunicação, apresenta, conforme Charaudeau (2008), três funções ou comportamentos: alocutivo, quando se estabelece uma relação de influência entre locutor e interlocutor; elocutivo, quando se revela o ponto de vista do locutor; e delocutivo, presente na retomada da fala de um terceiro.

No comportamento alocutivo, o sujeito falante, ao enunciar sua posição sobre o mundo, implica, com seu dizer, o interlocutor e, ao impor um comportamento, ele age sobre esse interlocutor. O sujeito falante, na instância de sua enunciação, atribui papéis linguageiros a si e ao interlocutor. Ou ele se enuncia em uma posição de inferioridade em relação ao interlocutor e assume papéis nos quais necessita do "saber" e do "poder fazer" do interlocutor, ou se enuncia em posição de superioridade relativamente ao interlocutor. Nesse último caso, atribui a si papéis "que impõem ao interlocutor a execução de uma ação ("fazer fazer"/"fazer dizer")" (CHARAUDEAU, 2008, p. 82). Estabelece-se, dessa forma, entre ambos uma relação de força.

No comportamento elocutivo, o sujeito falante enuncia o seu ponto de vista sobre o mundo sem implicar o interlocutor. O resultado dessa tomada de posição "é uma enunciação que tem como efeito modalizar subjetivamente a verdade do propósito enunciado, revelando o ponto de vista interno do sujeito falante" (CHARAUDEAU, 2008, p. 83).

Já no comportamento delocutivo, o sujeito se coloca como testemunha da maneira pela qual "os discursos do mundo (provenientes de um terceiro) se impõem a ele" (CHARAUDEAU, 2008, p. 83). O resultado é uma enunciação aparentemente objetiva, desvinculada do locutor e do interlocutor, como no discurso relatado.

Para cada um desses comportamentos enunciativos, correspondem categorias da língua, conforme Charaudeau (2008, p. 85).

No comportamento alocutivo, encontram-se as categorias modais: Interpelação, Injunção, Autorização, Aviso, Julgamento, Sugestão, Proposta, Interrogação e Petição. No elocutivo: Constatação, Saber/Ignorância, Opinião, Apreciação, Obrigação, Possibilidade, Querer, Promessa, Aceitação/Recusa, Acordo/Desacordo, Declaração e Proclamação. No delocutivo: a Asserção e o Discurso Relatado.

Postulamos, em nosso estudo, que os comportamentos enunciativos evidenciam marcas linguístico-discursivas do ethos do enunciador, por meio das quais se revela sua personalidade, conforme considerações de Maingueneau (2001). Acreditamos que as relações de força ou de pedido, assinaladas pelas categorias modais que o locutor estabelece com o interlocutor no modo locutivo, assim como o comportamento que se configura linguisticamente nas modalidades elocutivas, permitem examinar as cenografias que ocorrem nos comentários dos leitores da Superinteressante online, a fim de averiguar como eles constroem o seu ethos discursivo na interação com o interlocutor.

\section{Metodologia}

O corpus geral da pesquisa contou com 40 notícias de divulgação científica extraídas da aba Ciência do site da revista Superinteressante online a partir do mês de janeiro de 2017. As notícias que divulgavam resultados de pesquisa ou descoberta científica foram retiradas seguindo uma ordem sequencial até completarem 40 exemplares. No layout da tela em que aparecia a notícia, após ela, seguiam-se informes publicitários e, na parte final da página, situava-se o espaço dos comentários.

Todas as notícias do corpus apresentaram comentários: 28 notícias tinham apenas um comentário; oito, dois comentários; dois, três comentários; quatro, um comentário; um, dez comentários. Foram, ao todo, 64 comentários, dos quais 28 traziam críticas negativas quanto: à falta de informações; à incompletude de conteúdo dos textos; à organização do plano de texto da notícia; à linguagem empregada; à explicação científica oferecida a um fenômeno do mundo; ao ponto de vista do locutor; ou a opções retóricas do locutor. 
$\mathrm{Na}$ pesquisa, realizou-se uma análise qualitativa desses 28 comentários, sustentada pela base teórica exposta. Para os fins deste artigo, do conjunto de comentários negativos, selecionamos dois que se sobressaíram devido à riqueza de marcas linguísticas relativas ao Modo de Organização Enunciativo. Em outras palavras, detivemo-nos nos comentários mais significativos do ponto de vista das marcas linguísticas enunciativas, averiguando como o ethos discursivo dos leitores-comentaristas se constrói na interação com o interlocutor.

\section{A análise dos comentários}

O comentário online é um gênero discursivo próprio do webjornalismo e apresenta características específicas, como a de possibilitar a interação direta com o interlocutor, a quem o comentarista dirige a sua fala. Para Noguera Vivo (2016), os comentários como os que se encontram nas revistas online são uma adaptação digital de um esquema tradicional e hierárquico já conhecido: o jornalista tem espaço para publicar por sua condição profissional e, ao leitor, cabe a audiência. Embora o leitor se manifeste nos comentários, apenas ocasionalmente obtém retorno, pois o meio, conforme Noguera Vivo (2016, p. 74) "raramente se preocupa em gerir, monitorar e filtrar com o objetivo de obter novas histórias ou de dar continuidade ou de verificar aquilo que publica". A ideia, assim, de que os comentários online se constituiriam em algo totalmente novo no campo do webjornalismo, perde um pouco de força.

De qualquer forma, considerando a cena genérica que realizam, ainda que as revistas dificilmente deem retorno aos comentaristas, esses têm seus textos publicados após as notícias, confirmando uma interatividade comunicativa, de acordo com os princípios do webjornalismo, na qual o leitor, usuário da rede, busca interagir com o meio.

Ressalte-se que é comum, nos comentários na web, os comentaristas interagirem entre si. Nesta pesquisa, porém, nos focamos unicamente nos comentários dirigidos aos jornalistas ou à revista.

A Superinteressante online é editada pelo Grupo Abril e é acessada por um público predominante jovem. Segundo a Publiabril $^{3}, 58 \%$ de seus leitores são do sexo masculino e $42 \%$, do feminino. Desses, $33 \%$ têm de 25 a 34 anos e $24 \%$, de 15 a 24 anos. Em texto editorial, a revista afirma que o seu site, "para quem ama conhecimento e diversão" e apresenta "um mix completo de ideias, ciência, tecnologia, cultura pop, comportamento e história. Tudo com uma pegada Super de enxergar as

\footnotetext{
3 Disponível em: http://publiabril.abril.com.br/marcas/superinteressante/ plataformas/site. Acesso em: 30 maio 2017.
}

coisas" (PUBLIABRIL, 2018). Ou seja, ela se vende como uma revista atual e dirigida aos jovens.

Apresentaremos, na sequência, a análise de dois comentários que se dirigiram a notícias, buscando evidenciar a construção do ethos discursivo dos comentaristas ao examinarmos o seu comportamento enunciativo. Saliente-se que não nomeamos os comentaristas.

E quais são as fontes dessas pesquisas feitas, Super? Trazer uma notícia que começa com um pedaço de uma música de pagode e informações vagas só descredibiliza a matéria! De "superinteressante" não tem nada mais aqui. (Comentário I). ${ }^{4}$

O Comentário I, realizado em 17 de janeiro de 2017, seguiu-se à notícia redigida por Giselle Hirata, intitulada "Lua é mais velha do que cientistas imaginavam" (Anexo A). Seu fim discursivo é a divulgação de um estudo realizado por equipe de cientistas da Universidade da Califórnia (UCLA), que buscou identificar a idade exata da Lua.

Após o título, encontra-se o seguinte subtítulo (linha fina): "Tá vendo aquela Lua que brilha lá no céu? Ela nasceu só 60 milhões de anos após a formação do Sistema Solar”. Segue-se a isso o corpo da notícia com informações sobre a pesquisa, a metodologia empregada, os resultados, um comentário do pesquisador. Encontram-se ainda quatro hiperlinks:(1) "Universidade da Califórnia em Los Angeles (UCLA)"; (2) "revista"; (3) "os resultados"; (4) "a Lua foi formada por uma colisão violenta". Cada um deles encaminha a informações que complementam a notícia. Em (1), o hiperlink remete ao site da UCLA, contendo informações em inglês sobre a Universidade; (2) manda para a página principal do periódico em que a pesquisa foi publicada, a Science Advances; (3) dá acesso ao abstract e ao artigo acadêmico publicado na Science Advances, intitulado "Early formation of the Moon 4.51 billion years ago", que deu origem à notícia; (4) envia para uma notícia DC publicada pela própria Superinteressante online, intitulada $O$ incrivel nascimento da Lua, que explica a formação do satélite.

Quando o comentarista-leitor se enuncia, ele o faz por meio de uma Interrogação e de uma Interpelação, modalidades alocutivas: E quais são as fontes dessas pesquisas feitas, Super? A Interpelação estabelece uma relação de força com o interlocutor, na medida em que esse se vê obrigado a reconhecer-se como alvo do apelo que o identifica. Nesse caso, o interpelado não é propriamente a autora-jornalista, Giselle Hirata, mas a revista Superinteressante, como entidade. Ao chamar a

\footnotetext{
4 Comentário de leitor no site da Superinteressante, realizado na matéria "Lua é mais velha do que cientistas imaginavam”, disponível em: https:/ super.abril.com.br/ciencia/lua-e-muito-mais-velha-do-que-cientistasimaginavam/. Acesso em: 20 maio 2017
} 
Super, o enunciador coloca-se no papel enunciativo de quem atribui a si um estatuto que o autoriza a interpelar. A nomeação da Super revela uma certa advertência, já que a pergunta na qual a chamada se insere contém uma crítica a uma suposta falha pela falta de informação da fonte. Por meio da modalidade da Interrogação, o locutor estabelece com o seu enunciado uma informação a adquirir, impondo, ao interlocutor, o papel de "interrogado" e atribuindo a si o direito de questionar. Ainda que os hiperlinks remetam abundantemente a textos que embasaram a notícia, inclusive ao artigo acadêmico em que a pesquisa foi publicada, para o enunciador, as fontes da notícia não foram reveladas. Observa-se que, nessa primeira intervenção do leitor-comentarista, estabelece-se um tom desafiador, já revelando o seu ethos discursivo, ou seja, a imagem de alguém que provoca a revista ao revelar uma imperfeição, o que impele à inferência de que a Super deixa a desejar em termos de credibilidade.

Segue-se à Interrogação e à Interpelação, o Julgamento do locutor sobre o dito no subtítulo da notícia: "Trazer uma notícia que começa com um pedaço de uma música de pagode e informações vagas só descredibiliza a matéria!". Na modalidade enunciativa Julgamento (CHARAUDEAU, 2008), o locutor estabelece com seu enunciado uma ação realizada. O linguista postula que o interlocutor é responsável por esse ato, julga-o como bom ou mau, declara a sua aprovação ou desaprovação, atribui a si a autoridade moral daquele que pode julgar; já o interlocutor é tido como tendo realizado um ato de que seria responsável e se acha qualificado pelo julgamento do locutor.

No comentário em foco, o locutor julga, em primeiro lugar, a estratégia do interlocutor de trazer um verso da música Tá vendo aquela Lua, do grupo Exalta Samba - “Tá vendo aquela lua que brilha lá no céu?". Ele censura essa opção do locutor de aproximar-se do leitor não especialista por meio de uma letra de pagode, ação que acredita comprometer a seriedade da informação. À censura sobre o emprego do verso de pagode, seguese outro Julgamento: o de que a notícia apresenta informações vagas. O locutor atribui à notícia essas características desfavoráveis e afirma exclamativamente que isso acarreta tão somente descrédito (ele emprega o termo "descredibiliza"). Note-se que o locutor utiliza a exclamação ao final de seu julgamento. Essa pontuação é marca de postura enunciativa, segundo Dahlet (2002), pois expressa sentimentos, como "surpresa, admiração, espanto, piedade, súplica, medo" (DAHLET, 2002, p. 39). Na manifestação do leitor-comentarista, a exclamação marca linguisticamente um estado emocional de irritação frente à ação considerada condenável por ele.

Encerrando a sua fala, o comentarista afirma: "De "superinteressante" não tem nada mais aqui". O locutor trata, nesse momento, de mostrar sua Opinião, uma modalidade elocutiva. Na Opinião, esclarece Charaudeau (2008, p. 93), da parte do locutor:

um fato ou afirmação é pressuposta e a partir daí o locutor explicita a posição que o fato ou a informação ocupam em seu universo de crenças. Assim, o locutor avalia a verdade de seu propósito e, ao mesmo tempo, revela qual é seu ponto de vista.

O interlocutor, por sua vez, não está implicado e é testemunha da opinião do locutor. Nesse caso, o fato pressuposto é a afirmação do comentarista de que a notícia não apresenta fontes, usa um verso de pagode para inserir o tema da pesquisa que identificou mais exatamente a idade da Lua e oferece informações vagas ao leitor. O caráter afirmativo da Opinião mostra a convicção do locutor frente ao que disse; além disso, ele usa aspas no qualificativo "superinteressante", uma maneira de ironizar o nome da revista, negando a ela o atributo que lhe dá esse nome.

Os comportamentos enunciativos do locutor revelam a forma como ele se constrói frente ao interlocutor, nesse caso, a revista Superinteressante. A cenografia elaborada mostra um enunciador que se autoriza a interpelar e a interrogar, questionando a credibilidade da notícia. Apresenta-se em posição de superioridade, o que dá a seu discurso um tom pretensioso, de quem se incomoda com a ligação entre letras de pagode e temas científicos estabelecida pelo interlocutor enquanto produtor da notícia, como se isso a desmerecesse. Ele se coloca como fiador do que diz na medida em que erige a sua fala julgando fatos que apresenta como verdadeiros, ainda que possam não o ser. A notícia, na verdade, apresenta as suas fontes, que são nomeadas no corpo do texto: "equipe de cientistas da Universidade da Califórnia em Los Angeles (UCLA), foi publicado na revista Science Advances"; "Kevin McKeegan, professor de geoquímica e química cosmológica da UCLA e co-autor do estudo". Além disso, essas passagens carregam hiperligações que remetem a dados detalhados dos pesquisadores e de sua investigação: o site da UCLA e do periódico Science Advances, assim como do artigo acadêmico. Dessa forma, a notícia não oferece apenas informações vagas como ele sentencia.

O ethos discursivo desse locutor comentarista aponta para uma identidade compatível com as posições que ele sustenta em seu comentário, pois constrói uma imagem de si de alguém que detém conhecimentos sobre procedimentos próprios do domínio da ciência, como a necessidade de citar fontes ou de se restringir aos dados da pesquisa.

A questão que se apresenta diante de tal ethos é que essa construção de si contrasta com as evidências de ser ele um leitor que não coopera com o interlocutor ao não 
trilhar as possibilidades oferecidas pelas hiperligações, assim como parece desconhecer o contrato midiático de popularização da ciência, julgando a notícia com critérios da divulgação no meio acadêmico. Dessa forma, revelase um leitor com pouca familiaridade com o formato da notícia digital: ele não assume postura participativa para colaborar da cocriação da informação por meio das possibilidades que as hiperligações oferecem.

Senhorita Ana Carolina Leonardi,

Parabéns pela ótima descrição da pesquisa, porém seria prudente uma matéria com mais informações, afinal o título nos motiva a crer que essa descoberta também se aplica a nós, seres humanos. Então, ao longo do texto nos deparamos com a informação de que, até agora, somente sabemos que a descoberta se aplica a ratos. Acredito que o último parágrafo fez o leitor se identificar, mostrando como essa descoberta nos afeta, afetou e afetará. (Comentário II). ${ }^{5}$

O Comentário II, de 27 de abril de 2017, segue-se à notícia (Anexo B), intitulada "Olfato é moldado de acordo com a experiência de vida", redigida pela jornalista Ana Carolina Leonardi. O fim discursivo é o de divulgar resultados de pesquisa que verificou, em ratos, que o olfato é moldado pela experiência. Após o título, lê-se o subtítulo: "Até gêmeos (pelo menos, de ratos) começam a cheirar diferente, apesar do nariz geneticamente igual". Em seguida, após uma foto em close de um focinho de cachorro, tem-se o corpo do texto. Nos três primeiros parágrafos, a jornalista se dirige ao leitor e usa a terceira pessoa - "seu nariz", "seus olhos", "seu paladar", "seu repertório de cheiros", "seus genes" -, remetendo a experiências pessoais do leitor. Do quarto parágrafo em diante, o texto retoma o enfoque do subtítulo, que informa ter sido a pesquisa realizada com ratos, detalhando-a brevemente. No último parágrafo, há a retomada das experiências olfativas próprias dos seres humanos.

Segue-se na página, após anúncios comerciais de produtos variados, o comentário do leitor, que inicia com uma Interpelação seguida de um Julgamento:

Senhorita Ana Carolina Leonardi,

Parabéns pela ótima descrição da pesquisa, porém seria prudente uma matéria com mais informações, afinal o título nos motiva a crer que essa descoberta também se aplica a nós, seres humanos.

$\mathrm{Na}$ Interpelação, o locutor se dirige à jornalista usando um pronome de tratamento, senhorita, o que imprime um matiz respeitoso à interlocução. Depois disso, ele a

\footnotetext{
5 Comentário de leitor no site da Superinteressante, realizado na matéria "Olfato é moldado de acordo com a experiência de vida", disponível em: https://super.abril.com.br/ciencia/olfato-e-moldado-de-acordo-coma-experiencia-de-vida/. Acesso em: 20 maio 2017.
}

parabeniza pela "ótima descrição da pesquisa", marcando a presença da modalidade enunciativa de Julgamento. Na sequência do comentário, observa-se que o tratamento obsequioso faz parte da construção de um modo cortês de interagir com o interlocutor. Na continuidade, sobrevém uma contraposição, marcada pelo conector, "porém”, com uma posição que parece contradizer a aprovação inicial expressa pelo comentarista.

Insere-se, a partir da presença desse conector, a modalidade alocutiva da Sugestão, comportamento enunciativo no qual o locutor (CHARAUDEAU, 2008, p. 89) estabelece com seu enunciado uma ação a realizar (ou a não realizar); propõe ao interlocutor a execução de uma ação descrita como meio para melhorar a situação do interlocutor, que se encontra em uma posição desfavorável; atribui a si um estatuto de saber. O interlocutor, por sua vez, é tido como envolvido em uma situação desfavorável; torna-se beneficiário de uma proposta de fazer para melhorar sua situação e é dotado de liberdade para utilizar ou não a proposta.

No comentário, o locutor sugere à jornalista que ela redija uma notícia "com mais informações", ainda que na proposição anterior a tivesse parabenizado pela "ótima descrição da pesquisa". Observe-se o emprego da expressão "seria prudente", que revela o conselho que o comentarista dá à jornalista sobre como melhor redigir o texto. Parece haver, nessa passagem, uma contradição do comentarista; no entanto, atribuímos essa incoerência aparente à manobra realizada por ele para atenuar as críticas que tece sobre o fazer da jornalista. Revela-se, por meio da maneira respeitosa como se dá a Interpelação e o Julgamento, o tom que ele deseja imprimir ao comentário: o da crítica polida.

O locutor atribui a si o estatuto de saber que lhe permite sugerir. A justificativa para o conselho proposto, articulado a partir do operador "afinal", é o informe, para ele inesperado, de que a descoberta não se aplica a humanos:

afinal o título nos motiva a crer que essa descoberta também se aplica a nós, seres humanos. Então, ao longo do texto nos deparamos com a informação de que, até agora, somente sabemos que a descoberta se aplica a ratos.

Ou seja, a experiência da leitura do título e do corpo do texto o orienta para a ação de sugerir modificações na redação da notícia. Essa construção do comentário aponta a cenografia de um leitor que quer se mostrar atento à construção do texto, embora o subtítulo expresse, desde o início, que se trata de uma experiência com ratos: "Até gêmeos (pelo menos, de ratos) começam a cheirar diferente, apesar do nariz geneticamente igual". Concomitantemente, o vocativo inicial empregado remete à cenografia da carta, lembrando as tradicionais cartas do leitor. 
Na parte final do comentário, o leitor tece sua Opinião: "Acredito que o último parágrafo fez o leitor se identificar, mostrando como essa descoberta nos afeta, afetou e afetará". Na modalidade elocutiva da Opinião, o locutor explicita a posição que um fato ou informação ocupa em seu universo de crença, sem implicar o interlocutor. Aqui, o fato é o conteúdo do último parágrafo da notícia, que, na continuidade do parágrafo anterior, projeta pesquisas futuras para além de um estudo com ratos: com mamíferos e, em especial, com seres humanos. O enunciador da notícia, no último parágrafo, condiciona essa possibilidade e diz que se trata de hipótese apenas. No período final, para apontar a importância das repercussões da pesquisa, remete o leitor a experiências comuns e afetivas: os odores das pessoas que amamos. É sobre esse conteúdo que o comentarista tece sua Opinião. Após o Julgamento negativo, ele contrapõe um aspecto positivo da composição da notícia, expressando a sua Opinião ("Acredito que o último parágrafo fez o leitor se identificar...”). A sua fala evidencia, por outro lado, que a estratégia do produtor da notícia de destacar a relevância da pesquisa foi exitosa, pois houve o reconhecimento de que a descoberta científica o afeta sobremaneira.

A cenografia que se constrói do comentarista dessa notícia é, enfim, a de um leitor atento que, como em uma carta ao leitor tradicional, dirige-se à Ana Carolina Leonardi. Ele se mostra como alguém que acompanha a continuidade temática do texto e que é capaz de atestar a competência redacional da jornalista. Essa posição revela o ethos discursivo desse locutor. Ao se referir a partes específicas do texto e ao apontar problemas, que, a seu ver, prejudicam a leitura e que poderiam afastar os leitores, porque esses não se sentiriam afetados pela pesquisa; ele mostra-se fiador do que diz.

Entretanto, cabe lembrar que, na verdade, em seu comentário, ele omitiu o fato de que o subtítulo da notícia já informava tratar-se de uma pesquisa experimental com ratos. Essa ocorrência mostra que, embora a representação de si seja a de um leitor cuja competência leitora respalda os seus julgamentos e opiniões, a simples conferência das informações expostas na notícia perturba essa imagem projetada.

\section{Considerações finais}

Buscamos evidenciar, na análise dos dois comentários, que a atenção ao comportamento enunciativo do leitorcomentarista nos leva à construção do ethos discursivo projetado. O discurso, desenvolvido a partir de uma cenografia, institui uma cena de enunciação que legitima a sua fala. As cenografias produzidas mostram que esses locutores constroem uma identidade enunciativa compatível com o fim discursivo de seus comentários. Eles autoatribuem papéis que os autorizam a julgar, a opinar, a interpelar, tudo isso respaldado por um fiador, construído na cenografia, que concede legitimidade para suas críticas.

A palavra dos leitores-comentaristas não suscita nenhuma resposta por parte da revista, apesar de ela ter sido instituída como interlocutora. Mesmo assim, ocorre o protagonismo desses locutores, manifestado quando são publicados seus comentários em seguida à notícia. Confirma-se, assim, a ideia de "transferência de poder" (CANAVILHAS, 2014) própria da Interatividade do webjornalismo, na qual o leitor tem o poder da palavra e a possibilidade de ganhar visibilidade.

Nos dois comentários analisados, destacou-se o comportamento alocutivo, distribuído nas categorias Interrogação, Interpelação e Julgamento no primeiro comentário, e Interpelação, Sugestão e Julgamento no segundo comentário. Emergiu igualmente o comportamento elocutivo, em ambos os comentários, a partir da categoria Opinião. Por outro lado, não houve presença de categoria do ato delocutivo.

A partir das análises, constatamos que os comentários sempre refletem as posições dos enunciadores na condição de leitores-comentaristas, e isso se expressa por intermédio das marcas linguísticas da enunciação. Ou seja, sempre há a ação enunciativa nos comentários, por meio da qual o leitor-comentarista deixa seu feedback sobre a matéria lida.

No decorrer da presente pesquisa, vimos que todo discurso que está inserido no domínio midiático necessita assumir as duas finalidades do contrato de comunicação, as chamadas "visadas" de Charaudeau (2009), as quais estão na tensão entre fazer-saber (informar) e fazer-sentir (captar).

Por isso, quando um leitor-comentarista realiza um comentário negativo sobre a matéria divulgada, esse comentário se reflete diretamente nessas visadas, uma vez que, para ele, o divulgador não informou de forma clara e/ou correta ou não o conquistou enquanto leitor, nem o fez "sentir".

Por fim, salientamos que os comentários dos interlocutores, uma característica do webjornalismo, permitem algo precioso: o contato com a recepção dos leitores, o que não acontece tão frequente e imediatamente na mídia impressa.

\section{Referências}

AMOSSY, Ruth (org.). Imagens de si no discurso: a construção do ethos. São Paulo: Contexto, 2005.

CANAVILHAS, João (org.). Webjornalismo: 7 características que marcam a diferença. Covilhã: Livros LabCom, 2014. Disponível em: www.labcom-ifp.ubi.pt/ficheiros/20141204-201404 webjornalismo_jcanavilhas.pdf. Acesso em: 03 nov. 2016. 
CANAVILHAS, João. Webjornalismo: considerações gerais sobre webjornalismo na web. [S. l.: s. n.], 2001. Disponível em: http:// www.bocc.ubi.pt/pag/canavilhas-joao-webjornal.pdf. Acesso em: 15 maio 2018.

CHARAUDEAU, Patrick. Linguagem e discurso: modos de organização. São Paulo: Contexto, 2008.

CHARAUDEAU, Patrick. O discurso das mídias. São Paulo: Contexto, 2006.

CHARAUDEAU, Patrick. Sobre o discurso científico e sua midiatização. Calidoscópio, São Leopoldo, v. 14, n. 3, p. 550-556, 2016. https://doi.org/10.4013/cld.2016.143.17

DAHLET, Véronique. A pontuação e sua metalinguagem gramatical. Revista de Estudos da Linguagem, Belo Horizonte, v. 10, n. 1, p. 29-41, 2002. https://doi.org/10.17851/22372083.10.1.29-41

HIRATA, Giselle. Lua é mais velha do que cientistas imaginavam. Superinteressante, 13 jan. 2017. Disponível em: https://super.abril.com.br/ciencia/lua-e-muito-mais-velha-do-quecientistas-imaginavam/. Acesso em: 13 mar. 2017. https://doi. org/10.26512/2016.03.d.20585

LEONARDI, Ana Carolina. Olfato é moldado de acordo com a experiência de vida. Superinteressante, 27 abr. 2017. Disponível em: https://super.abril.com.br/ciencia/olfato-e-moldado-deacordo-com-a-experiencia-de-vida/. Acesso em: 30 mar. 2017. https://doi.org/10.15601/1679-6098/tp.v2n3p17-23

MAINGUENEAU, Dominique. Análise de textos de comunicação. Tradução de Cecília P de Souza-e-Silva e Décio Rocha. São Paulo: Cortez, 2001. https://doi.org/10.18309/anp.v1i12.518

MAINGUENEAU, Dominique. Cenas da enunciação. Curitiba: Criar Edições, 2006.

MAINGUENEAU, Dominique. Discurso e análise do discurso. Tradução de Sírio Possenti. São Paulo: Parábola, 2015.
MAINGUENEAU, Dominique. Doze conceitos em análise do discurso. Tradução de Maria Cecília Pérez Souza-e-Silva e Sírio Possenti. São Paulo: Parábola, 2010. v. 1. https://doi. org/10.18309/anp.v1i12.518

MAINGUENEAU, Dominique. Ethos, cenografia, incorporação. In: AMOSSY, Ruth (org.). Imagens de si no discurso: a construção do ethos. São Paulo: Contexto, 2005. p. 69-92.

NOGUERA VIVO, José Manuel. Todos, todo: manual de periodismo, participación y tecnología. Barcelona: Universitat Oberta De Catalunya, 2016.

PALACIOS, Marcos. Jornalismo online, informações e memória: apontamentos para debate. Porto: Universidade de Beira Interior, 2002. Disponível em: labcom-ifp.ubi.pt/files/agoranet/02/ palacios-marcos-informacao-memoria.pdf. Acesso em: 15 out. 2015.

PRIMO, Alex; TRÄSEL, Marcelo Ruschel. Webjornalismo participativo e a produção aberta de notícias. Contracampo, Niterói, v. 14, p. 37-56, 2006. https://doi.org/10.22409/ contracampo.v0i14.512

ROST, Alejandro. Interatividade: definições, estudos e tendências. In: CANAVILHAS, João (org.). Webjornalismo: 7 características que marcam a diferença. Covilhã: Livros LabCom, 2014. Disponível em: www.labcom-ifp.ubi.pt/ ficheiros/20141204-201404_webjornalismo_jcanavilhas.pdf. Acesso em: 03 nov. 2016.

ROST, Alejandro. La interactividad en el periódico digital. 2006. Tese (Doutorado em Periodisme y Ciències de la Comunicació) - Programa de Doctorat en Periodisme y Ciències de la Comunicaciò, Departament de Periodisme y Ciències de la Comunicació, Facultat de Ciències de la Comunicació, Universitat Autònoma de Barcelona, Bellaterra, 2006. Disponível em: https://ddd.uab.cat/pub/tesis/2006/tdx-1123106-104448/ ar1de1.pdf. Acesso em: 15 maio 2017. https://doi.org/10.17345/ comeduc200115-19

\section{ANEXO A \\ Matéria "Lua é muito mais velha do que cientistas imaginavam"}

\section{Lua é muito mais velha do que cientistas imaginavam}

Tá vendo aquela Lua que brilha lá no céu? Ela nasceu só 60 milhões de anos após a formação do Sistema Solar.

Uma senhora Lua! Durante décadas, cientistas discutem a idade exata do satélite natural da Terra. Agora, pesquisadores acreditam ter chegado a um número mais aproximado: 4.51 bilhões de anos - entre 40 e 140 milhões de anos a mais do que se imaginava.

O estudo, realizado por uma equipe de cientistas da Universidade da Califórnia em Los Angeles (UCLA), foi publicado na revista Science Advances. A descoberta também mostrou que a Lua teria se formado apenas 60 milhões de anos depois do nascimento do Sistema Solar, e 40 milhões depois da Terra. As novas informações são cruciais para os estudos sobre a evolução inicial do nosso planeta.

Os resultados foram baseados em análises feitas em zirconitas, minerais trazidos por astronautas da missão Apollo 14, em 1971. Várias técnicas já foram utilizadas para determinar a idade de pedras lunares, mas a maioria é composta por uma mistura de rochas de diferentes períodos e origens - o que sempre dificultou o trabalho dos pesquisadores. 
Desta vez, porém, foi possível estudar zirconitas em estado puro e analisar a redução da atividade radioativa do urânio nas rochas. "Elas são os melhores relógios da natureza", disse Kevin McKeegan, professor de geoquímica e química cosmológica da UCLA e co-autor do estudo. "É o mineral que preserva a história geológica, revelando onde foi originado".

Os cientistas acreditam que isso torna o olfato de cada rato único, apesar das semelhanças genéticas. O próximo passo é entender se o mesmo processo se aplica a todos os mamíferos - e a nós.

Se confirmada, a hipótese ajuda a explicar a interação de fatores ambientais e genéticos em parte da nossa experiência de mundo. Além, é claro, de trazer à tona uma implicação bem fofa: de que o nosso corpo reage perante odores (e multiplica os sensores olfativos) conforme eles se tornam familiares - como, quem sabe, o cheiro da casa da avó ou o perfume da pessoa amada. (HIRATA, 2017)

\section{ANEXO B \\ Matéria "Olfato é moldado de acordo com a experiência da vida"}

\section{Olfato é moldado de acordo com a experiência da vida}

Até gêmeos (pelo menos, de ratos) começam a cheirar diferente, apesar do nariz geneticamente igual.

Cheiro de livro, de carro novo, de bolo saindo do forno: são todos cheiros familiares para todo mundo. Mas ninguém sente esses cheiros exatamente igual. Foi o que concluiu uma pesquisa do Instituto Wellcome Trust Sanger, que estudou o olfato em ratos.

Seu nariz é muito mais sensível que os seus olhos e o seu paladar: são cerca de mil receptores responsáveis pelo olfato.

$\mathrm{O}$ "seu repertório de cheiros" vem da combinação de sinais que cada um desses receptores captura do ambiente. E, a princípio, a distribuição de receptores no seu nariz depende dos seus genes.

Isso os pesquisadores verificaram no estudo: o nariz de ratos tem 10 milhões de células. Cada célula tem um receptor, selecionado dos mil tipos de receptor existentes. Só isso já possibilita uma enorme variedade de combinações. Ratos geneticamente idênticos nasciam com a mesma seleção de receptores, explicando a origem genética das "configurações de fábrica" do olfato.

Mas a surpresa aconteceu depois. Eles separaram os ratinhos, que passaram a viver em ambientes diferentes. E aí o olfato começou a mudar. Conforme os ratos tinham experiências diferentes com o mundo ao seu redor, o número de células com um mesmo tipo de receptor começou a variar muito entre os gêmeos.

Tudo dependia da exposição dos animais a cada cheiro. Se um rato era mais acostumado aos cheiros doces, passava a ter mais células com receptores de identificação desses odores, por exemplo. Se era exposto a perfumes cítricos, mais receptores desse tipo de fragrância. E assim, o aparelho olfativo já tinha uma cara bem diferente do que aquele programado geneticamente logo após o nascimento.

Os cientistas acreditam que isso torna o olfato de cada rato único, apesar das semelhanças genéticas. O próximo passo é entender se o mesmo processo se aplica a todos os mamíferos - e a nós.

Se confirmada, a hipótese ajuda a explicar a interação de fatores ambientais e genéticos em parte da nossa experiência de mundo. Além, é claro, de trazer à tona uma implicação bem fofa: de que o nosso corpo reage perante odores (e multiplica os sensores olfativos) conforme eles se tornam familiares - como, quem sabe, o cheiro da casa da avó ou o perfume da pessoa amada. (LEONARDI, 2017)

Recebido em: 15/6/2018.

Aprovado em: 7/10/2019.

Publicado em: 30/11/2019.

\section{Autores:}

Maria EduARda GiERING

Doutora, professora titular da Universidade do Vale do Rio dos Sinos, São Leopoldo, RS, Brasil.

Orcid: https://orcid.org/0000-0001-8098-4238

E-mail: eduardajg@gmail.com

EdUARDO PARÉ GLÜCK

Mestre, Universidade do Vale do Rio dos Sinos, São Leopoldo, RS, Brasil.

Orcid: https://orcid.org/0000-0001-5032-9582

E-mail: eduardogluck@gmail.com

Endereço: Av. Unisinos, 950 - Cristo Rei

93022-750, São Leopoldo, RS, Brasil 